\title{
INSTALASI KOMPUTER DAN PENGGUNAAN E-INFO PADA SMA N 1 KEFAMENANU
}

\author{
Claria Fransiska Agatha Berek $^{1)}$,Siprianus Septian Manek ${ }^{2)}$ \\ Teknologi Informasi, Fakultas Pertanian, Universitas Timor, Indonesia ${ }^{1), 2)}$

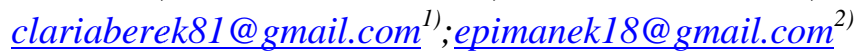

\begin{abstract}
Abstrak
Teknologi informasi dan komunikasi saat ini telah berkembang sangat pesat di masyarakat, terutama di kalangan para pelajar. Akan tetapi masih banyak yang belum bisa memanfaatkan Teknologi informasi dan komunikasi dengan baik seperti masalah yang terjadi pada SMA N 1 Kefamenanu. Pemanfaatan Teknologi informasi dan komunikasi pada sekolah tersebut belum maksimal dikarenakan sarana dan prasarana pada laboratorium komputer yang ada pada SMA N 1 Kefamenanu masih ada beberapa komputer yang rusak maupun belum terinstall sistem operasi. Dari permasalah di atas, maka dilakukan kegiatan pengabdian dengan judul Instalasi Komputer Dan Penggunaan E-Info Pada SMA N 1 Kefamenanu. Hasil kegiatan pengabdian kepada masyarakat ini yaitu: penggunaan laboratorium komputer menjadi lebih maksimal dan dengan pengenalan pemanfaatan e-info pada siswa, sehingga siswa dapat menerapkan pengunaan teknologi informasi dan komunikasi pada proses belajar mengajar di SMA N 1 Kefamenanu.
\end{abstract}

Kata Kunci: E-Info, Instalasi, Kefamenanu, Komputer

\begin{abstract}
Information and communication technology has now developed rapidly in community, especially among students. However, there are still many who have not been able to utilize it properly, such as the problem that occurred in SMAN 1 Kefamenanu. Utilization of information and communication technology in this school has not been maximized due to facilities and infrastructure in the computer laboratory in SMAN 1 Kefamenanu. There are still a number of damaged computers or operating systems that have not been installed. From the problems above, the service activity was carried out with the title Computer Installation and Use of E-Info at SMAN 1 Kefamenanu. The results of the community service activities were: the use of computer laboratory becomes more maximal and with the introduction of the use of einfo to students, so students can apply the use of information and communication technology in the teaching and learning process in SMAN Kefamenanu.
\end{abstract}

Keywords: E-Info, Installed, Kefamenanu, Computer

\section{PENDAHULUAN}

Dalam meningkatkan kualitas sumber daya manusia Indonesia terutama dalam dunia kerja diperlukan suatu kemampuan tersendiri atau keterampilan dalam peningkatan ilmu pengetahuan dan teknologi komputer. Salah satu cara menigkatkan keterampilan dan pengetahuan tentang teknologi komputer adalah dengan mengikuti materi atau mata pelajaran dasar tentang Teknologi Informasi dan Komputer (TIK) pada pendidikan Sekolah Menengah, seperti yang diterapkan pada SMAN 1 Kefamenanu.

Sekolah Menengah Atas Negeri 1 Kefamenanu merupakan lembaga pendidikan yang terakreditasi B yang beralamatkan di Jl. Sobay, Kefamenanu, Nusa Tenggara Timur. Sekolah ini memiliki peserta didik sebanyak 312 Siswa Laki-laki dan 543 Siswa Perempuan serta 43 guru. 
Fasilitas yang ada di sekolah ini antara lain 27 ruangan belajar, ruang guru dan kepala sekolah, perpustakaan, 4 laboraturium dan kamar mandi. Fasilitas ruang komputer disediakan sebagai sarana belajar siswa di waktu pelajaran TIK. Selain itu, ruang komputer juga akan digunakan sebagai laboratorium percontohan ujian sekolah berbasis komputer.

Komputer yang ada pada laboratorium komputer di Sekolah Menengah Atas Negeri 1 Kefamenanu sejumlah 40 unit. Hal ini dirasa sudah mencukupi untuk proses pembelajaran namun dikarenakan sarana dan prasarana pada laboratorium komputer yang belum siap atau rusak maka pemanfaatan teknologi informasi dan komunikasi pada sekolah tersebut belum maksimal. Bebeberapa komputer pada laboratorium SMA Negeri 1 Kefamenanu rusak dan belum terinstal sistem operasi sehingga terkadang siswa juga lebih suka membawa laptop sendiri ketika pelajaran TIK.

Berdasarkan pembahasan dan masalah diatas, maka perlu dilakukan kegiatan pengabdian masyarakat untuk instalasi dan servis komputer pada SMA Negeri 1 Kefamenanu. Pengabdian masyarakat adalah suatu kegiatan yang bertujuan membantu masyarakat tertentu dalam beberapa aktivitas tanpa mengharapkan imbalan dalam bentuk apapun. Secara umum program ini dirancang oleh berbagai universitas atau institut yang ada di Indonesia untuk memberikan kontribusi nyata bagi bangsa Indonesia, khususnya dalam mengembangkan kesejahteraan dan kemajuan bangsa Indonesia. Kegiatan Pengabdian Masyarakat merupakan salah satu bagian dari Tri Dharma Perguruan Tinggi.

Selain dilaukan instalasi dan servis komputer, perlu juga dilakukan pengenalan E-Info bagi siswa SMA Negeri 1 Kefamenanu. Hal ini dilakukan untuk melatih dan meningkatkan kemampuan siswa dalam menggunakan dan memanfaatkan teknologi Informasi. E-Info atau Informasi Elektronik adalah satu atau sekumpulan data elektronik, termasuk tetapi tidak terbatas pada tulisan, suara, gambar, peta, rancangan, foto, electronic data interchange (EDI), surat elektronik (electronic mail), telegram, teleks, telecopy atau sejenisnya, huruf, tanda, angka, Kode Akses, simbol, atau perforasi yang telah diolah yang memiliki arti atau dapat dipahami oleh orang yang mampu memahaminya.

Secara umum, kegiatan pengabdian masyarakat dengan judul "Instalasi Komputer dan Pengunaan E-Info pada pada SMA Negeri 1 Kefamenanu” ini diharapkan dapat meningkatkan pemanfaatan teknologi informasi dan komunikasi pada dunia pendidikan.

\section{METODE}

\section{Tempat dan Waktu Pengabdian}

Kegiatan pengabdian ini akan dilaksanakan pada bulan September sampai bulan Oktober, Tahun Ajaran 2018/2019, setiap minggu selama dua bulan di SMAN 1 Kefamenanu.

\section{Alat}

a. Penginstalan komputer:
a) Flasdisk $8 \mathrm{~GB}$
b) hardisk $500 \mathrm{~GB}$
c) Obeng

b. Pengenalan E-info: 

a) 1 buah Laptop Acer
b) Proyektor
c) 1 buah handphone Xiomi MI A1, 2 buah Samsung Gstar-S7262

\section{Bahan}

Komputer, perangkat lunak,

\section{Metode}

Metode yang digunakan dalam kegiatan ini yaitu mahasiswa akan memeriksa masalah pada komputer dan memperbaikinya, serta melakukan kegiatan penginstalan sesuai yang diminta petugas laboratorium komputer dan untuk kegiatan pengenalan E-info mahasiswa melakukan penjelasan di depan kelas, serta praktek penggunaan E-info yang ditampilkan pada layar melalui proyektor dan dari presentasi dan praktek, ada sesi tanya jawab antara siswa, mahasiswa dan dosen.

\section{Out Put Pengabdian}

1. Teknik

a. Komputer dapat beroperasi dengan baik

b. Siswa dapat menggunakan e-info untuk mengecek nilai maupun melihat materi

2. Peserta

Yang menjadi peserta dalam kegiatan penginstalan komputer adalah mahasiswa prodi Teknik Informatika Universitas Timor yang berjumlah 5 orang dan peserta untuk pengenalan e-info adalah siswa-siswa kelas X IPA.

\section{Prosedur Kegiatan}

Untuk mewujudkan tujuan pengabdian di atas, maka langkah-langkah yang akan ditempuh adalah sebagai berikut :

a. Melakukan koordinasi (pertemuan) dengan pihak sekolah, dalam hal ini Kepala Sekolah SMA N 1 Kefamenanu, untuk mendiskusikan topik yang akan diabdikan.

b. Melakukan pengabdian setiap minggu selama dua bulan

c. Memberikan pelatihan penggunaan aplikasi e-info kepada siswa.

\section{HASIL DAN PEMBAHASAN}

Hasil yang dicapai pada kegiatan instalasi komputer adalah beberapa komputer yang sebelumnya rusak ataupun belum terinstal sistem operasi sekarang dapat dioperasikan dan digunakan secara maksimal khususnya pada mata pelajaran TIK dan mata pelajaran lain yang berhubungan dengan komputer sedangkan hasil yang dicapai pada kegiatan pengenalan e-info adalah siswa dapat memanfaatkan e-info untuk mengecek nilai mata pelajaran dan juga dapat berkomunikasi dengan guru terkait dengan materi dan tugas pembelajaran lewat media e-info.

\section{KESIMPULAN}

Berdasarkan hasil pengabdian yang telah dilakukan maka dapat disimpulkan :

1. Komputer dapat beroperasi dengan baik

2. Siswa dapat menggunakan e-info untuk mengecek nilai maupun melihat materi.

\section{UCAPAN TERIMA KASIH}


Pengabdian ini telah terlaksana dengan maksimal dan mendapatkan bantuan dari berbagai pihak sehingga tak lupa penulis mengucapkan banyak terima kasih kepada :

1. Prof.Dr. Sirilus Seran, S.E., M.Si selaku Rektor Universitas Timor

2. Dr. Paulus Klau Tahuk, S.Pt., M.P, selaku Ketua LPPM Unimor

3. Dr. Ir. Stefanus Sio, M.P, selaku Dekan Fakultas Pertanian Universitas Timor

4. Drs.Yoseph Obe, selaku Kepala Sekolah SMA N 1 Kefamenanu

5. Esen, S.Kom selaku Kepala Laboratorium Komputer SMA N 1 Kefamenanu dan sebagai guru TIK

6. Kepada semua pihak yang telah berkontribusi dalam pelaksanaan pengabdian masyarakat ini.

\section{DAFTAR PUSTAKA}

Arifandi, Muh. Modul Pengelola Instalasi Komputer Lengkap. 2016.

Daulay, Melwin Syafrizal. Mengenal Hardware-Software \& Pengelolaan Instalasi Komputer. Yogyakarta: Andi Offset, 2009.

Sopandi, Dede. Instalasi dan Konfigurasi Jaringan Komputer (edisi revisi). Jakarta: INFORMATIKA, 2008. 